\title{
Van-e védelem a másolás ellen? Gondolatok a plágiumról*
}

\author{
Schubert András ${ }^{1}$. Wolfgang Glänzel ${ }^{1,2}$ \\ ${ }^{1}$ MTA Könyvtár és Információs Központ, Tudománypolitikai és Tudományelemzési Osztály, Budapest \\ ${ }^{2}$ KULeuven, Leuven, Belgium
}

\begin{abstract}
Annak, hogy a tudományos szakirodalomban egyre növekvő számú plágiumgyanús esetet észlelünk, legalább két oka van. Egyrészt az erősödő publikációs nyomás hatására a szerzők, a bírálók és a szerkesztők is könnyebben áthágják, illetve elnézik ezt a súlyos etikai vétséget, másrészt a szövegelemző szoftverek fejlődésével a szövegazonosságok kimutatása egyszerú feladattá vált. A konkrét esetek megítélése azonban megalapozott szakmai ismereteket és körültekintő emberi döntést igényel. Orv. Hetil., 2015, 156(50), 2052-2053.
\end{abstract}

Kulcsszavak: tudománymetria, publikációs etika, plágium

\section{Is there protection against copying? Thoughts about plagiarism}

There are at least two reasons why more and more cases of suspected plagiarism are perceived in the scientific literature. On one hand, the ever strengthening publication pressure makes easier for the authors, reviewers and editors to infringe or overlook this serious ethical misdemeanor; on the other hand, with the development of text analysis software, detecting text similarities became a simple task. The judgement of actual cases, however, requires well-grounded professional knowledge and prudent human decisions.

Keywords: scientometrics, publication ethics, plagiarism

Schubert, A., Glänzel, W. [Is there protection against copying? Thoughts about plagiarism]. Orv. Hetil., 2015, $156(50), 2052-2053$.

(Beérkezett: 2015. június 2.; elfogadva: 2015. június 25.)

Ha valaki több évtizedet tölt a tudományos publikáció világában szerzőként, bírálóként és szerkesztőként, aligha kerülheti el, hogy bizonyos etikai kérdésekkel szembesüljön. A kutatók végső soron esendő emberek, és egyáltalában nem mentesek a hiúság, irigység és féltékenység bűneitôl. A spektrum széles: az adatok közötti enyhén tendenciózus válogatástól a durván meghamisított eredményekig, a vetélytársak eredményeinek szórakozott elfeledésétől a vitathatatlan plágiumig. Garfield [1] külön kiemeli a kriptomnézia jelenségét, amely „nem tudatos plágium, amikor is újnak tûnő, kreatív ötletek valójában mások gondolatainak elő nem hívott emlékei”.

A plágium definíciója változatos. Az Oxford szótár szerint a plágium „mások munkájának vagy gondolatainak sajátként történő továbbadása”. Ez a definíció egyértelműen szándékos csalást és becstelenséget feltételez. A Webster szerint a plágium „mások szavainak vagy gondolatainak hivatkozás nélküli használata”. A két definíció közötti különbség csekély, de lényeges: a Webster szerin- ti plágium gondatlanság vagy véletlen kihagyás eredménye is lehet. Bár nem azonos súlyúak, mind a két változat etikátlan és a szerzői jogok megsértését eredményezi.

A plágium jelensége egyáltalában nem új, ha úgy tetszik, a régi görögökig vagy még messzebbre vezethető vissza. A legújabb kori fejlemények közül két tényezőt érdemes kiemelni, amelyek bizonyos értelemben ellentétes irányban hatnak.

Az egyik az ezerszer elátkozott „Publikálj vagy pusztulj!” szemlélet nyomása. Nyomás nehezedik a szerzőkre a minden áron való „termelés” irányába, és ez csökkentheti az erkölcsi gátlásokat. Nyomás nehezedik a bírálókra, hogy betartsák a feszítő határidőket, és explicit és egyértelmú véleményt mondjanak esetleg azon az áron, hogy kevésbé merülnek el a kézirat anyagában. És nyomás nehezedik a szerkesztőkre is, hogy megtöltsék a kiadó által előírt terjedelmet a kiadó által elvárt eladási, letöltési és idézettségi számokat produkáló cikkekkel. Ez a hármas nyomás nyilvánvalóan megnöveli az esélyét an- 
nak, hogy kétes erkölcsi alapokon nyugvó kéziratok kerüljenek közlésre.

A másik oldalon megjelent egy egyre gyarapodó eszköztár a különféle deviáns publikációs viselkedések felismerésére. A szövegelemző szoftverek megtalálják a többszörös publikációkat (még fordítások esetében is), vagy a szövegegyezéseket akár egyazon, akár különböző szerzők szövegeiben. Az utóbbi esetben, ha a korábbi szövegre nincsen megfelelő hivatkozás, jogosan vetődik fel a plágium gyanúja. A szövegegyezés magas százaléka azonban eredhet különféle ártatlan okokból is: sztenderd definíciók ismétlése, idioszinkratikus módszertani leírások, sőt közös hivatkozások is okozhatnak szövegegyezésre utaló jelzéseket. A gyanú tehát még nem ítélet. Ahogyan a tudománymetriai mutatószámok a kutatásértékelésben, a szövegelemzés kvantitatív adatai segíthetik, de nem helyettesítik a szakértő emberi mérlegelést.

Nemrégiben Necker [2] egy cikkében mennyiségileg vizsgálta a közgazdászok attitűdjét a plagiarisztikus viselkedéssel szemben, valamint, hogy mennyiben tekintik a publikációs „nyomást” lehetséges oknak. Arra a következtetésre jutott, hogy a professzionális közgazdászok körében széles körü egyetértés van azokat a normákat illetően, amelyeknek a kutatói viselkedést irányítani kellene. Ugyanakkor a közgazdászok számottevő mértékben elismerik, hogy esetenként eltértek ezektől a normáktól. Az eredmények azt jelzik, hogy a publikációs nyomás pozitívan korrelál a közgazdászok többsége által elítélt kutatói viselkedésformák gyakorlásával.

Egészen hasonló eredményeket hozott egy 315 flamand orvosbiológiai kutatóra vonatkozó vizsgálat [3]. A vizsgálat résztvevőinek $15 \%$-a ismerte be, hogy a megelőző 3 évben valamilyen módon megsértette a publikációs etikára vonatkozó szabályokat. A vétségek legnagyobb részét az egyetemi klinikákon dolgozó fiatal kutatók követték el (vagy legalábbis ők ismerték be). Közel háromnegyedük tartotta túlzottnak a rájuk nehezedő publikációs nyomást, amit erősen felelősnek tartottak az etikai szabályok áthágásáért.

Érdekes szempontot vet fel Robinson [4] a mostanság sokat kárhoztatott önplágiumot („szöveg-újrahasznosítást”) illetően. Véleménye szerint e vétség súlyossága erősen szakterületfüggő. Az orvosi területeken például, ahol a klinikai tesztek hatékonyságának megítélésében a szakirodalom metaanalízise is szerepet játszik, a szövegek megsokszorozása erôsen torzíthatja a valós megítélést. Másutt (például a társadalomtudományok egyes területein) ez a gyakorlat teljesen ártalmatlan lehet.

A fentiek megmagyarázzák a szerkesztők és kiadók zavarát, amikor plágiumgyanús esetekkel találkoznak. Milyen szemszögből ítéljek meg a szerzőket? Véletlen szövegegyezésről van szó? Hanyagságból maradt ki az átmásolt szöveg forrására való hivatkozás? Vagy szándékos volt a lopás?

Sietünk leszögezni, hogy a plágium minden formája etikai vétség és elfogadhatatlan. De, mint ahogy egy $\mathrm{Na}$ ture-jegyzet [5] és az azt követő megjegyzések nemrégi- ben hangsúlyozták: a szankcióknak árnyaltaknak kell lenniük és a vétséget megfelelő keretbe kell helyezni. Igazságtalan a plágiumot kikiáltani fó gonosznak csak azért, mert a jelenlétét a hozzá nem értők is könnyen fel tudják fedezni. Minden esetet természetesen hozzáértő szakemberekkel gondosan meg kell vizsgáltatni, akik azután tetten érhetnek olyan - néha sokkal súlyosabb - etikai problémákat is, amelyek nem olyan nyilvánvalóak.

A mérlegelés nagyon fontos; az ítéletnek, a büntetésnek szigorúnak, de arányosnak kell lenni. A túl enyhe ítélet hatástalan lehet, míg egy feleslegesen kemény súlyos károkat okozhat a szerző karrierjében. A plágium esetében, mint a bünügyekben, az ártatlanság vélelme kötelező.

Bármennyire abszurdnak hangzik is, a plágium - bár súlyos vétség azok ellen, akiknek a terhére elkövették valójában nem károsítja lényegesen magát a tudományos ismeretanyagot. Egy kopipésztelt matematikai tétel igaz marad, egy kémiai szintézis akkor is múködik, ha egy eltulajdonított ötletet tartalmazó dokumentumban találtunk rá. Ezzel szemben a manipulált eredmények, hamisított bizonyítékok, téves statisztikai következtetések súlyos károkat okozhatnak, ha beépülnek az elfogadott tudásanyagba. Arról pedig csak álmodozhatunk, hogy ezek felismerésére is olyan hatékony eszközeink lesznek, mint a plágium esetére.

Addig csak olyanok maradunk, mint a viccbeli részeg ember, aki a lámpaoszlop alatt keresi az elvesztett kulcsát. Nem ott vesztette el, de ott van világos.

Anyagi támogatás: Schubert András köszöni az FP7SSH-2013-2 \#613202 (IMPACT-EV) projekt támogatását.

A cikk végleges változatát a szerzők elolvasták és jóváhagyták.

Érdekeltségek: A szerzőknek nincsenek érdekeltségeik.

\section{Irodalom}

[1] Garfield, E.: Uses and misuses of citation frequency. Essays Inform. Sci., 1985, 8, 403-409.

[2] Necker, S.: Scientific misbehavior in economics. Res. Policy, 2014, 43(10), 1747-1759.

[3] Tijdink, J. K., Verbeke, R., Smulders, Y. M.: Publication pressure and scientific misconduct in medical scientists. J. Empir. Res. Human Res. Ethics, 2014, 9(5), 64-71.

[4] Robinson, S. R.: Self-plagiarism and unfortunate publication: an essay on academic values. Studies Higher Educ., 2014, 39(2), 265-277.

[5] Chaddah, P.: Not all plagiarism requires a retraction. Nature, 2014, 511(7508), 127.

[6] Glänzel, W., Schubert, A.: Plagiarism: A non-apology. ISSI Newsletter, 2014, 10(2), 27-28.

[7] Glänzel, W., Braun, T., Schubert, A., et al.: Coping with copying. Scientometrics, 2015, 102(1), 1-3.

(Schubert András e-mail: schuba@iif.hu) 